\title{
PEMANTAPAN KEMAMPUAN MENGAJAR BERBASIS LESSON STUDY DI PROGRAM MAGISTER PENDIDIKAN IPA UNIVERSITAS MATARAM
}

\section{THE ENHANCEMENT OF LESSON STUDY BASED TEACHING CAPABLITIES IN POSTGRADUATE PROGRAM OF SCIENCE EDUCATION UNIVERSITY OF MATARAM}

\author{
Gito Hadiprayitno $^{1 *}$, Baiq Niswatul Khair ${ }^{2}$ \\ ${ }^{1}$ Program Studi Pendidikan Biologi, Jurusan Pendidikan MIPA, Fakultas Keguruan dan Ilmu Pendidikan, \\ Universitas Mataram. Jalan Majapahit No 62 Mataram, 83125, Indonesia \\ ${ }^{2}$ Program Studi Pendidikan Guru Sekolah Dasar, Fakultas Keguruan dan Ilmu Pendidikan, Universitas Mataram. \\ Jalan Majapahit No 62 Mataram, 83125, Indonesia \\ *E-mail: gitohadiprayitno@unram.ac.id
}

Diterima: 01 Maret 2018. Disetujui: 28 Maret 2018. Dipublikasikan: 31 Maret 2018

\begin{abstract}
Abstrak. Penelitian ini bertujuan untuk mendeskripsikan praktik pembelajaran dengan menggunakan prinsip lesson study yang melibatkan 6 orang mahasiswa program magister pendidikan IPA Universitas Mataram. Praktik pembelajaran dengan pola lesson study ini dilakukan di SMP 4 Lingsar selama 2 bulan (OktoberNovember 2016). Setiap mahasiswa berkesempatan untuk berperan sebagai guru model selama 2 kali, dan 10 kali pertemuan lainnya bertindak sebagai observer. Langkah-langkah lesson study berupa tahap plan, do, see dilakukan dalam 2 seting yang berbeda, sebagian besar tahap plan dilaksanakan di kampus sedangkan tahap do dan see dilaksanakan di sekolah. Adapun temuan dari penelitian ini antara lain (1) proses belajar pembelajaran dengan pola lesson study ini secara umum dinilai menarik bagi siswa, meskipun masih ada beberapa siswa yang kurang serius dan kurang disiplin seperti berbicara, bercanda, atau mengganggu teman lainnya saat pembelajaran berlangsung, (2) perlu adanya persiapan yang lebih matang dari tim, khususnya guru model sebelum kegiatan pembelajaran dilaksanakan, (3) perlu upaya yang lebih optimal untuk meningkatkan kemampuan guru dalam manajemen kelas, (4) terdapat beberapa masalah teknis di luar kendali atau faktor guru, yakni kurangnya dukungan daya listrik, bel tanda akhir pembelajaran berbunyi sebelum waktunya, dan rombongan belajar yang terlalu besar.
\end{abstract}

Kata kunci: lesson study, diskusi kelompok, praktik mengajar, SMP 4 Lingsar

\begin{abstract}
This study was intended to describe teaching practice by 6 students of graduate program of science education in the University of Mataram used lesson study. It was conducted at SMP 4 Lingsar for about 2 months (October - November 2016). Each student teacher (model teacher) was assigned to teach twice and to observe others' teaching for 10 times. Most of the 'plan' stage was done at campus, whereas the 'do' and 'see' at the practicum site. The results of this study show (1) The teaching and learning process by the model teachers was found generally interesting for students, although some students indicated lack of seriousness, discipline, such as talking to the classmates or disrupting other students, (2) There needs to be better preparation before the teaching activity to improve quality of teaching and observation, (3) There should be more work to improve teachers' skills in managing the classroom, and (4) There were some problems still related to the teaching and learning process but beyond the teacher control, such as lack of power supply, school bell ringing before time and the class size which is too big.
\end{abstract}

Keywords: lesson study, group discussion, teaching practice, SMP 4 Lingsar.

\section{PENDAHULUAN}

Matakuliah Pemantapan Kemampuan Mengajar (PKM) merupakan matakuliah wajib yang harus diambil oleh mahasiswa Program Studi Magister Pendidikan IPA di Universitas Mataram. Tidak berbeda dengan matakuliah yang ada di tempat lain, PKM secara umum berisi tentang pengenalan lapangan (sekolah), latihan keterampilan mengajar, dan latihan terbimbing untuk mendukung terwujudnya pencapaian kompetensi yang harus dimiliki oleh guru diantaranya ialah kompetensi pedagogik, kepribadian, profesional, dan sosial.
Keempat kompetensi tersebut bersifat holistik dan integratif dalam kinerja guru. Oleh karena itu secara utuh sosok kompetensi guru meliputi (a) pengenalan peserta didik secara mendalam, (b) penguasaan bidang studi baik disiplin ilmu maupun bahan ajar dalam kurikulum sekolah, (c) penyelenggaraan pembelajaran yang mendidik yang meliputi perencanaan dan pelaksanaan pembelajaran, evaluasi proses dan hasil belajar, serta tindak lanjut untuk perbaikan, dan (d) pengembangan kepribadian dan profesionalitas secara berkelanjutan [1]. 
Pelaksanaan kegiatan perkuliahan PKM dilakukan dengan 2 mekanisme yaitu pertemuan tatap muka dan praktek mengajar yang dilakukan di sekolah mitra. Sementara itu operasionalisasi kegiatan belajar mengajarnya dilakukan dengan menggunakan Lesson Study. Penggunaan Lesson Study ini didasari oleh pertimbangan bahwa Lesson Study merupakan salah satu model pengembangan profesi guru yang telah terbukti memberikan kontribusi positif dalam memperbaiki kegiatan pembelajaran [2]. Keutamaan dari Lesson Study adalah dapat meningkatkan keterampilan dan kecakapan dalam melakukan kegiatan pembelajaran yang dilakukan guru melalui belajar dari suatu pembelajaran [3]. Hasil penelitian lain juga menyatakan hal yang sama [4]. Lesson Study merupakan model pembinaan (pelatihan) profesi pendidik melalui pengkajian pembelajaran secara kolaboratif dan berkelanjutan berlandaskan prinsipprinsip kolegialitas dan mutual learning untuk membangun komunitas belajar [5]. Lebih lanjut dijelaskan bahwa di Jepang, Lesson Study ditempatkan pada semua area kurikulum, meskipun sebagian besar diterapkan pada pembelajaran matematika dan sains dibandingkan area lain [6]. Karena itu, berbagi pengalaman dalam melaksanakan kegiatan pembelajaran yang telah dilakukan selama ini merupakan cara yang efektif untuk menciptakan masyarakat belajar seperti yang diharapkan dalam kegiatan Lesson Study. Perkuliahan PKM diampu oleh seorang dosen yang berperan dalam memfasilitasi kegiatan tatap muka di kampus dan mendampingi praktek mengajar yang dilaksanakan di sekolah. Perkuliahan dalam bentuk tatap muka yang dilaksanakan di kampus dipergunakan untuk mendiskusikan hal-hal yang terkait dengan pengenalan dan penyamaan persepsi tentang Lesson Study, dan melakukan kegiatan pengamatan pelaksanaannya melalui penayangan video.

Kegiatan tatap muka digunakan untuk menyempurnakan perangkat pembelajaran tahap Plan yang dilakukan secara kolaboratif antara dosen dan mahasiswa yang menjadi observer dalam tahap $d o$. Dengan demikian, perangkat pembelajaran yang dibuat dapat menghasilkan pembelajaran yang efektif dan mampu membangkitkan partisipasi aktif siswa. Tahapan Do dan see dilaksanakan di sekolah. Tahap do difokuskan dalam mengimplementasikan perangkat pembelajaran. Salah seorang mahasiswa bertindak sebagai guru model, sedangkan yang lain sebagai pengamat (observer). Mahasiswa yang menjadi guru model dan pengamat disepakati dalam perkuliahan tatap muka dan dilaksanakan secara bergiliran sehingga semua mahasiswa memiliki kesempatan yang sama untuk menjadi guru model dan pengamat.

Hasil akhir dari perkuliahan pemantapan kemampuan mengajar ini dibuat laporannya secara individual dan makalah ini membahas secara komprehensif pelaksanaan kegiatan perkuliahan pemantapan kemampuan mengajar berbasis Lesson Study yang ada di Program Studi Magister IPA Universitas Mataram yang telah diimplementasikan di SMP 4 Lingsar, Kecamatan Narmada, Kabupaten Lombok Barat. Informasi yang disampaikan dalam makalah ini diharapkan dapat memberikan kontribusi dalam memperbaiki kegiatan pembelajaran terutama bagi guru dan mahasiswa calon guru serta menginspirasi pihak-pihak terkait dalam mengimplementasikan Lesson Study untuk pengembangan profesi guru.

\section{METODE PENELITIAN}

Penelitian ini merupakan penelitian deskriptif model survei. Subyek penelitian terdiri dari 6 orang mahasiswa Program Studi Magister IPA Universitas Mataram yang memprogramkan matakuliah PKM. Kegiatan perkuliahan dimulai pada bulan September sampai dengan bulan Desember 2016. Perkuliahan pada minggu pertama difokuskan pada penjelasan dan penyamaan persepsi tentang Lesson Study, sedangkan perkuliahan pada minggu kedua difokuskan pada penayangan video dan pembuatan instrumen yang diperlukan dalam pembelajaran berbasis Lesson Study. Perkuliahan pada tahap selanjutnya membahas tentang penyempurnaan tahapan Plan, do dan see. Tahapan penyempurnaan Plan dilaksanakan di kampus, sedangkan tahapan do dan see dilaksanakan di sekolah mitra yaitu SMP 4 Lingsar, Kecamatan Narmada, Kabupaten Lombok Barat. Identitas mahasiswa yang menjadi guru model dalam pelaksanaan Lesson Study dibuat nama inisial model seperti M1-NI, M2-HS, M3-AA, M4-EK, M5-KM, dan M6-MH. Hal ini dilakukan untuk menghindari penilaian yang bersifat subjektif kepada yang bersangkutan. Demikian juga dengan identitas mahasiswa yang menjadi pengamat, diinisialkan namanya menjadi pengamat $1(\mathrm{P} 1)$, pengamat $2(\mathrm{P} 2)$, pengamat $3(\mathrm{P} 3)$, pengamat $4(\mathrm{P} 4)$, pengamat $5(\mathrm{P} 5)$, dan pengamat 6 (P6). Setiap mahasiswa mendapat kesempatan untuk melaksanakan kegiatan pembelajaran berbasis Lesson Study sebanyak 2 kali dan sebagai pengamat sebanyak 10 kali. Selama pelaksanaan kegiatan pembelajaran berbasis Lesson Study di SMP 4 Lingsar, guru IPA yang mengajar di sekolah tersebut bahkan kepala sekolah, dilibatkan selama do dan see untuk melakukan kegiatan pengamatan dan memberikan masukan pada saat refleksi. Disamping itu, pelibatan guru lain dan kepala sekolah dalam pelaksanaan pembelajaran ini diharapkan sebagai media sosialisasi pada para guru dan stakeholder lain dalam mengimplementasikan dan mengembangkan pola pembelajaran berbasis Lesson Study. Karena itu, sebelum pembelajaran dimulai diawali dengan kegiatan briefing kepada para pengamat, guru dan kepala sekolah untuk menginformasikan kegiatan pembelajaran yang 
direncanakan oleh guru model dan mengingatkan bahwa selama pembelajaran berlangsung pengamat tidak diperkenankan mengintervensi kegiatan pembelajaran dengan cara mengobrol, memberikan bantuan kepada siswa pada saat berdiskusi atau berlalu lalang di dalam kelas. Pengamat fokus mencatat aktivitas dan perilaku siswa selama pembelajaran dengan mengacu pada pedoman observasi yang telah disepakati pada saat Plan. Posisi pengamat dikondisikan sedemikian rupa sehingga dapat melakukan pengamatan secara leluasa tanpa menggangu aktivitas siswa dan guru yang sedang melaksanakan kegiatan pembelajaran. Pada akhir kegiatan pembelajaran guru memberikan angket kepada siswa untuk mendapatkan informasi tentang (a) ketertarikan siswa dalam pembelajaran, (b) informasi penting yang diperoleh dalam pembelajaran, (c) hal-hal yang perlu ditingkatkan dalam pembelajaran, dan (4) hal-hal yang tidak penting dilakukan dalam pembelajaran.

Tahap selanjutnya dari kegiatan pemantapan kemampuan mengajar berbasis lesson study dalam penelitian ini ialah See yang dilakukan sesaat setelah pembelajaran berlangsung. Refleksi diawali dengan penyampaian kesan-kesan dalam pelaksanaan pembelajaran yang disampaikan oleh guru model. Selanjutnya pengamat diberikan untuk menyampaikan komentar dari hasil pengamatan kegiatan pembelajaran terutama yang berkaitan dengan aktivitas siswa. Penyampaian komentar dilakukan secara bergiliran yang dipimpin seorang moderator sehingga semua pengamat diberikan kesempatan untuk menyampaikan hasil pengamatannya.

Tabel 2. Rangkuman Informasi Kondisi Pembelajaran yang Diperoleh Melalui Angket Siswa

\begin{tabular}{|c|c|c|c|c|c|c|}
\hline \multirow{2}{*}{$\begin{array}{l}\text { Informasi } \\
\text { Kegiatan } \\
\text { Pembelajaran }\end{array}$} & \multicolumn{6}{|c|}{ Guru Model } \\
\hline & M1-NI & M2 - HS & $\mathrm{M} 3-\mathrm{AA}$ & M4 - EK & M5-KM & M6 - MH \\
\hline $\begin{array}{l}\text { Ketertarikan } \\
\text { siswa dalam } \\
\text { pembelajaran }\end{array}$ & $\begin{array}{l}\text { Melakukan } \\
\text { pengamatan } \\
\text { organ } \\
\text { pencernaan } \\
\text { menggunakan } \\
\text { torso dan } \\
\text { charta serta } \\
\text { praktikum uji } \\
\text { makanan }\end{array}$ & $\begin{array}{l}\text { Pengamata } \\
\mathrm{n} \text { video dan } \\
\text { praktikum } \\
\text { hasil } \\
\text { fotosintesis }\end{array}$ & $\begin{array}{l}\text { Dapat } \\
\text { membedakan } \\
\text { hama dan } \\
\text { penyakit pada } \\
\text { tanaman }\end{array}$ & $\begin{array}{l}\text { Praktikum } \\
\text { tentang } \\
\text { fotosintesis } \\
\text { dan } \\
\text { mengetahui } \\
\text { efek samping } \\
\text { penggunaan } \\
\text { bahan kimia } \\
\text { dalam rumah } \\
\text { tangga }\end{array}$ & $\begin{array}{l}\text { Pengamatan } \\
\text { video tentang } \\
\text { proses } \\
\text { pernapasan }\end{array}$ & $\begin{array}{l}\text { Melakukan } \\
\text { kegiatan } \\
\text { pengamatan } \\
\text { tumbuhan } \\
\text { putri malu }\end{array}$ \\
\hline $\begin{array}{l}\text { Informasi } \\
\text { penting dalam } \\
\text { pembelajaran }\end{array}$ & $\begin{array}{l}\text { Mengetahui } \\
\text { organ-organ } \\
\text { pencernaan } \\
\text { dan cara uji } \\
\text { karbohidrat, } \\
\text { protein, dan } \\
\text { lemak dalam } \\
\text { makanan }\end{array}$ & $\begin{array}{l}\text { Penjelasan } \\
\text { tentang } \\
\text { proses } \\
\text { terjadinya } \\
\text { fotosintesis }\end{array}$ & $\begin{array}{l}\text { Mengetahui } \\
\text { jenis hama } \\
\text { dan penyakit } \\
\text { pada tanaman }\end{array}$ & $\begin{array}{l}\text { Mengetahui } \\
\text { faktor-faktor } \\
\text { yang } \\
\text { mempengaruhi } \\
\text { fotosintesis } \\
\text { dan bahan } \\
\text { kimia yang } \\
\text { terkandung } \\
\text { dalam } \\
\text { pembersih, } \\
\text { pemutih, dan } \\
\text { pewangi }\end{array}$ & $\begin{array}{l}\text { Mengetahui } \\
\text { organ-organ } \\
\text { pernapasan }\end{array}$ & $\begin{array}{l}\text { Informasi } \\
\text { tentang } \\
\text { teknik } \\
\text { melakukan } \\
\text { pengamatan } \\
\text { pada } \\
\text { tumbuhan } \\
\text { putri malu }\end{array}$ \\
\hline $\begin{array}{l}\text { Hal yang } \\
\text { perlu } \\
\text { ditingkatkan } \\
\text { dalam } \\
\text { pembelajaran }\end{array}$ & $\begin{array}{l}\text { Keseriusan } \\
\text { dan } \\
\text { kedisiplinan } \\
\text { dalam belajar } \\
\text { pada saat } \\
\text { diskusi } \\
\text { kelompok } \\
\end{array}$ & $\begin{array}{l}\text { Waktu } \\
\text { praktikum } \\
\text { ditambah }\end{array}$ & $\begin{array}{l}\text { Keseriusan } \\
\text { dan } \\
\text { kedisiplinan } \\
\text { dalam belajar } \\
\text { pada saat } \\
\text { diskusi } \\
\text { kelompok } \\
\end{array}$ & $\begin{array}{l}\text { Waktu } \\
\text { pengamatan } \\
\text { ditambah }\end{array}$ & $\begin{array}{l}\text { Keseriusan dan } \\
\text { kedisiplinan } \\
\text { dalam belajar } \\
\text { pada saat } \\
\text { diskusi } \\
\text { kelompok }\end{array}$ & $\begin{array}{l}\text { Waktu } \\
\text { pengamatan } \\
\text { ditambah }\end{array}$ \\
\hline $\begin{array}{l}\text { Hal yang } \\
\text { tidak penting } \\
\text { dalam } \\
\text { pembelajaran }\end{array}$ & $\begin{array}{l}\text { Tidak } \\
\text { bermain pada } \\
\text { saat } \\
\text { belajar/diskus } \\
\text { i kelompok }\end{array}$ & $\begin{array}{l}\text { Tidak } \\
\text { bermain } \\
\text { pada saat } \\
\text { belajar/disk } \\
\text { usi } \\
\text { kelompok } \\
\end{array}$ & $\begin{array}{l}\text { Tidak } \\
\text { bermain pada } \\
\text { saat } \\
\text { belajar/diskus } \\
\text { i kelompok }\end{array}$ & $\begin{array}{l}\text { Tidak bermain } \\
\text { pada saat } \\
\text { belajar/diskusi } \\
\text { kelompok }\end{array}$ & $\begin{array}{l}\text { Tidak bermain } \\
\text { pada saat } \\
\text { belajar/diskusi } \\
\text { kelompok }\end{array}$ & $\begin{array}{l}\text { Tidak } \\
\text { bermain } \\
\text { pada saat } \\
\text { belajar/disku } \\
\text { si kelompok }\end{array}$ \\
\hline
\end{tabular}


Selanjutnya hasil refleksi dianalisis lebih lanjut secara deskriptif kualitatif untuk mengetahui dampak dari kegiatan pembelajaran yang dapat digunakan sebagai bahan perbaikan untuk pelaksanaan Lesson Study pada pertemuan berikutnya.

\section{HASIL DAN PEMBAHASAN}

Pada bagian ini akan diuraikan informasi terkait pelaksanaan pembelajaran menggunakan Lesson Study yang dilaksanakan di SMP 4 Lingsar. Informasi hasil penelitian dikelompokkan menjadi dua bagian yaitu (1) informasi tentang hasil angket siswa tentang kegiatan pembelajaran, dan (2) informasi tentang pelaksanaan Lesson Study yang dilaksanakan oleh tiap-tiap mahasiswa sebagai guru model mulai dari plan, do, dan see.

\section{Hasil Angket Siswa Terhadap Pembelajaran}

Pemberian angket pada siswa dilakukan ketika pembelajaran berbasis Lesson Study selesai dilakukan. Angket ini ditujukan untuk mendapatkan informasi tentang suasana pembelajran dilihat dari perspektif siswa. Rangkuman informasi yang diperoleh dari pemberian angket ke siswa dapat dilihat pada Tabel 2 .

Berdasarkan hasil analisis angket siswa pada Tabel 2 menunjukkan bahwa pembelajaran yang menggunakan video dan melakukan pengamatan secara langsung termasuk di dalamnya melakukan kegiatan praktikum merupakan faktor penting yang menjadikan siswa tertarik dalam melakukan kegiatan pembelajaran. Beberapa hasil penelitian menunjukkan bahwa siswa tertarik melakukan kegiatan pembelajaran apabila dilakukan dengan mengadakan pengamatan langsung baik menggunakan video [7] [8], praktikum [9] maupun melakukan kegiatan pengamatan lingkungan yang ada di sekitar sekolah [10]. Kegiatan pembelajaran dengan menggunakan pola seperti ini menyebabkan siswa dapat melakukan kegiatan secara kontekstual dan materi pembelajaran disampaikan dengan cara yang lebih konkrit. Kecenderungan pembelajaran selama ini yang hanya mengandalkan buku terutama pada pelajaran IPA, dapat mengakibatkan siswa kurang bersemangat dalam melaksanakan kegiatan pembelajaran. Di samping itu, pola pembelajaran yang hanya berorientasi pada buku teks memberi kesan pada siswa bahwa materi pelajaran IPA sulit dipahami karena berorientasi pada hapalan bukan membelajarkan materi yang terkait dengan permasalahan yang ditemukan dalam kehidupan sehari-hari [10].

Informasi lain yang diperoleh dari angket siswa pada pembelajaran (Tabel 2) menunjukkan bahwa meskipun pembelajaran sudah direncanakan dengan baik dan sebagian besar tertarik dengan kegiatan pembelajaran, terdapat beberapa hal yang perlu ditingkatkan dalam pembelajaran. Beberapa hal tersebut diantaranya ialah keseriusan dan kedisiplinan siswa dalam pembelajaran terutama pada saat diskusi kelompok, waktu pengamatan dan melaksanakan kegiatan praktikum yang perlu ditambah. Hal ini dapat terjadi karena jumlah siswa yang terlibat dalam setiap kali pembelajaran, jumlahnya melebihi dari rombongan belajar ideal. Berdasarkan ketentuan permendikbud no. 23 tahun 2013 setiap rombel untuk siswa SMP terdiri dari 20 sampai dengan 36 orang siswa. Akan tetapi rombel yang ada di SMP 4 Lingsar melebihi dari 36 orang siswa. Hal ini menyulitkan guru dalam melakukan pemantauan dan memfasilitasi pembelajaran siswa terutama pada saat diskusi dan melaksanakan kegiatan pengamatan atau praktikum. Konsekuensi dari kondisi tersebut ialah waktu mengadakan pengamatan dan praktikum yang tidak sesuai dengan jadwal yang sudah direncanakan sehingga pelaksanaan pembelajaran membutuhkan waktu yang lebih lama.

Jumlah rombel yang melebihi dari ketentuan berdampak yang kurang baik terhadap pembelajaran. Hal ini terlihat dari adanya kegiatan siswa yang melakukan aktivitas yang tidak penting dilakukan dalam pembelajaran. Aktivitas tersebut ialah adanya siswa yang ngobrol, bermain-bermain terutama pada saat diskusi kelompok berlangsung. Karena itu pada pembelajaran dengan jumlah rombel yang besar kemampuan guru dalam melakukan pengelolaan kelas perlu dioptimalkan dan idealnya jumlah guru yang melaksanakan kegiatan pembelajaran di kelas tersebut jumlahnya ditambah. Apabila kondisi tersebut tidak dimungkinkan perlu dipikirkan untuk membagi rombel menjadi dua kelas, sehingga memudahkan guru dalam memfasilitasi siswa pada saat pembelajaran berlangsung serta memudahkan guru dalam melakukan pemantauan aktivitas siswa selama diskusi maupun melaksanakan praktikum.

\section{Pelaksanaan Kegiatan Lesson Study}

Pelaksanaan Lesson Study yang dilakukan di SMP 4 Lingsar diawali dengan mendiskusikan perangkat pembelajaran (RPP, media pembelajaran, bahan ajar, LKS (Lembar Kerja Siswa), dan instrumen observasi pembelajaran) yang akan digunakan dalam pembelajaran. Diskusi perangkat ini dilaksanakan pada kegiatan Plan yang dilaksanakan pada pertemuan tatap muka di kampus Universitas Mataram. Sementara itu kegiatan Do dan See dilaksanakan di sekolah (SMP 4 Lingsar). Perangkaat pembelajaran yang dibuat oleh guru model menggunakan berbagai model pembelajaran yang sudah disesuaikan dengan materi. Materi IPA yang diajarkan dalam kegiatan pembelajaran terdiri dari memahami kegunaan bahan kimia dalam kehidupan disampaikan menggunakan model pembelajaran Kooperatif tipe number head together (NHT) dengan 
guru model M3 - AA dan guru model M4 - EK, memahami sistem dalam kehidupan tumbuhan disampaikan oleh guru model M2 - HS menggunakan model pembelajaran kooperatif tipe STAD, memahami sistem pencernaan makanan menggunakan model discovery learning disampaikan oleh guru model M1 - NI, memahami berbagai sistem dalam kehidupan manusia menggunakan model make a match disampaikan oleh guru model M5 - KM, dan memahami sistem dalam kehidupan tumbuhan yang disampaikan oleh guru model M6 - MH dengan menggunakan model pembelajaran direct intruction. Kegiatan penerapan pembelajaran di kelas dilakukan dengan berpedoman pada perangkat pembelajaran yang telah disusun sebelumnya pada tahapan plan. Pada tahapan terakhir yakni See, guru model memberikan kesan tentang proses pembelajaran yang dilakukan dan penyampaian hasil pengamatan yang dilakukan oleh observer untuk perbaikan pelaksanaan pembelajaran pada kegiatan berikutnya. Kegiatan refleksi pada tahap I dijadikan sebagai masukan untuk menyempurnakan rencana kegiatan pembelajaran pada tahap II. Hasil refleksi pada kegiatan Lesson Study tahap I (LS I) dan tahap II (LS II) dapat dilihat pada Tabel 3.

Tabel 3. Rangkuman Hasil Refleksi Pembelajaran pada Kegiatan Lesson Study Tahap I dan II

\begin{tabular}{|c|c|c|c|}
\hline $\begin{array}{l}\text { Guru } \\
\text { Model }\end{array}$ & Refleksi LS I & Refleksi LS II & Saran Perbaikan \\
\hline $\mathrm{M} 1-\mathrm{NI}$ & \begin{tabular}{|l} 
1. Ditemukan beberapa siswa \\
laki-laki yang mengganggu \\
siswa dari kelompok lain \\
pada saat pembelajaran \\
2. Ditemukan beberapa siswa \\
yang belum paham terhadap \\
tugas-tugas yang diberikan \\
3. Ditemukan siswa yang perlu \\
pendampingan secara khusus \\
karena melakukan aktivitas \\
berlebihan selama \\
pembelajaran
\end{tabular} & $\begin{array}{l}\text { 1. } \begin{array}{l}\text { Ditemukan beberapa siswa } \\
\text { tidak memahami prosedur } \\
\text { percobaan yang akan } \\
\text { dilakukan }\end{array} \\
\text { 2. } \\
\text { Ketersediaan bahan } \\
\text { praktikum yang terbatas } \\
\text { mengakibatkan siswa } \\
\text { berpindah ke kelompok lain } \\
\text { untuk melengkapi } \\
\text { kekurangan bahan praktikum }\end{array}$ & \begin{tabular}{|l} 
1. \\
Cara kerja yang tertuang \\
dalam LKS perlu dibacakan \\
terlebih dahulu sebelum \\
kegiatan diskusi kelompok \\
2. Manajemen kelas dan \\
pemantauan terhadap \\
aktivitas siswa selama \\
pembelajaran perlu \\
dioptimalkan
\end{tabular} \\
\hline $\mathrm{M} 2-\mathrm{HS}$ & \begin{tabular}{|l} 
1. \\
Konsentrasi belajar siswa \\
terganggu karena daya \\
listrik yang tidak mencukupi \\
untuk penayangan video dan \\
suara bel yang dibunyikan \\
lebih awal karena cuaca \\
mendung \\
2. \\
Ditemukan 6 orang siswa \\
yang tidak konsentrasi \\
belajar serta melakukan \\
aktivitas lain yang tidak \\
terkait dengan materi \\
pelajaran
\end{tabular} & $\begin{array}{l}\text { 1. Ditemukan kelompok yang } \\
\text { gagal dalam melakukan } \\
\text { percobaan karena desain } \\
\text { peralatan yang salah } \\
\text { 2. Konsentrasi belajar } \\
\text { kelompok ada yang } \\
\text { terganggu pada saat alat dan } \\
\text { bahan yang digunakan dalam } \\
\text { kegiatan praktikum } \\
\text { mengalami kekurangan } \\
\text { 3. Ditemukan beberapa siswa } \\
\text { meninggalkan kelompoknya } \\
\text { untuk melakukan aktivitas } \\
\text { berbeda dengan kelompok } \\
\text { lain }\end{array}$ & \begin{tabular}{|l} 
1. Penyampaian materi melalui \\
penayangan video \\
hendaknya disesuaikan \\
dengan kemampuan daya \\
listrik yang dimiliki sekolah \\
2. Guru perlu memberikan \\
kesempatan bertanya kepada \\
siswa sehingga siswa yang \\
belum memahami materi \\
bisa diketahui lebih dini \\
3. Peralatan dan bahan \\
praktikum dipersiapkan \\
secara maksimal sebelum \\
kegiatan pembelajaran \\
dilaksanakan
\end{tabular} \\
\hline $\mathrm{M} 3-\mathrm{AA}$ & 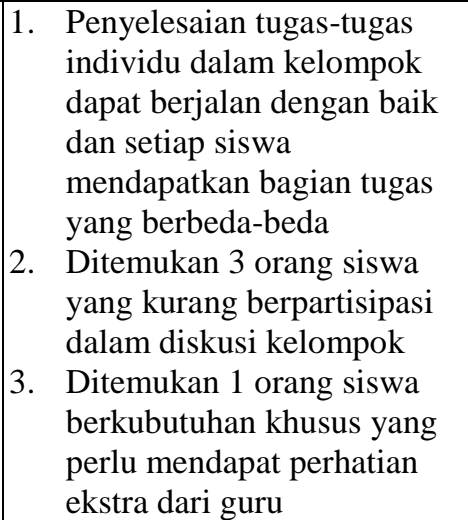 & $\begin{array}{l}\text { 1. Ditemukan } 2 \text { orang siswa } \\
\text { yang melakukan aktivitas } \\
\text { lain yang menggangu } \\
\text { suasana pembelajaran } \\
\text { 2. Penggunaan media kertas } \\
\text { berwarna menarik perhatian } \\
\text { siswa untuk fokus dalam } \\
\text { mengerjakan tugas-tugas } \\
\text { kelompok }\end{array}$ & \begin{tabular}{|l} 
1. \\
Pengelolaan kelas perlu \\
dioptimalkan dalam \\
menciptakan suasana belajar \\
yang kondusif \\
2. \\
Fasilitasi guru dalam \\
membimbing diskusi harus \\
dilakukan secara merata \\
pada semua kelompok
\end{tabular} \\
\hline
\end{tabular}




\begin{tabular}{|c|c|c|c|}
\hline $\begin{array}{l}\text { Guru } \\
\text { Model }\end{array}$ & Refleksi LS I & Refleksi LS II & Saran Perbaikan \\
\hline $\mathrm{M} 4-\mathrm{EK}$ & 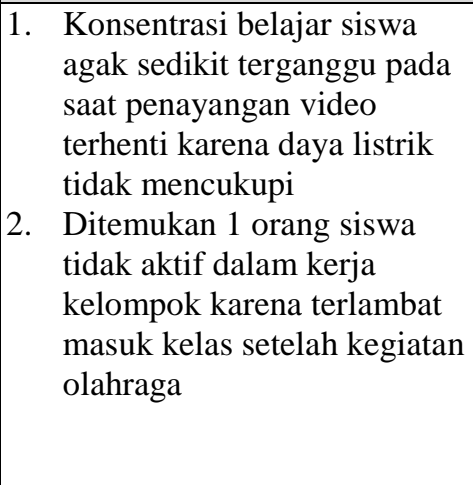 & $\begin{array}{l}\text { 1. Kegiatan praktikum siswa } \\
\text { terputus karena ada jam } \\
\text { istirahat yang mempengaruhi } \\
\text { konsentrasi belajar } \\
\text { 2. Sebagian besar siswa } \\
\text { mengalami kesulitan dalam } \\
\text { menghitug gelembung udara } \\
\text { (Oksigen) yang dihasilkan } \\
\text { dalam fotosintesis } \\
\text { 3. Beberapa siswa bermain- } \\
\text { bermain dan menggangu } \\
\text { kerja dalam kelompok }\end{array}$ & \begin{tabular}{|l} 
1. Perlu dipikirkan alternatif \\
penayangan video \\
pembelajaran yang sesuai \\
dengan kemampuan daya \\
listrik \\
2. \\
Perlu dipikirkan alternatif \\
lain dalam pemberian tugas \\
diskusi kelompok yang \\
memungkinkan semua siswa \\
berpartisipasi secara aktif
\end{tabular} \\
\hline $\begin{array}{l}\text { M5 } \\
\text { KM }\end{array}$ & $\begin{array}{l}\text { 1. Konsentrasi belajar siswa } \\
\text { terganggu pada saat ada } \\
\text { pembagian buku ketika } \\
\text { pembelajaran berlangsung } \\
\text { 2. Presentasi kelompok cukup } \\
\text { menggunakan perwakilan } \\
\text { saja tidak harus bergantian } \\
\text { 3. Setiap kelompok diberikan } \\
\text { charta yang cukup sehingga } \\
\text { tidak saling meminjam pada } \\
\text { kelompok lain } \\
\text { 4. LKS perlu disempurnakan } \\
\text { sehingga memudahkan } \\
\text { kelompok untuk } \\
\text { menyelesaikan tugas- } \\
\text { tugasnya } \\
\text { 5. Ditemukan beberapa siswa } \\
\text { yang melakukan aktivitas } \\
\text { lain pada saat guru model } \\
\text { melakukan kegiatan } \\
\text { demonstrasi }\end{array}$ & $\begin{array}{l}\text { 1. Tidak semua kelompok } \\
\text { melakukan presentasi hasil } \\
\text { diskusi karena kekurangan } \\
\text { waktu } \\
\text { 2. Peletakan charta yang } \\
\text { kurang tepat sehingga tidak } \\
\text { dimanfaatkan oleh siswa } \\
\text { secara maksimal } \\
\text { 3. Konsentrasi siswa terpecah } \\
\text { pada saat ada tayangan } \\
\text { video yang tidak sesuai } \\
\text { dengan materi pelajaran } \\
\text { 4. Ditemukan beberapa siswa } \\
\text { mengantuk dan kurang } \\
\text { bergairah dalam melakukan } \\
\text { diskusi kelompok }\end{array}$ & $\begin{array}{l}\text { 1. Motivasi dan semangat } \\
\text { belajar siswa perlu } \\
\text { distimulasi dengan } \\
\text { permainan atau game } \\
\text { 2. LKS perlu disempurnakan } \\
\text { disesuaikan dengan capaian } \\
\text { kompetensi yang diinginkan } \\
\text { 3. Pengelolaan waktu dan } \\
\text { manajemen kelas } \\
\text { diintensifkan untuk } \\
\text { menghindari siswa yang } \\
\text { tidak konsentrasi dan } \\
\text { melakukan aktivitas yang } \\
\text { lain } \\
\text { 4. Penanyangan video dan } \\
\text { penggunaan charta } \\
\text { disesuaikan dengan materi } \\
\text { pelajaran }\end{array}$ \\
\hline $\begin{array}{l}\text { M6 } \\
\text { MH }\end{array}$ & 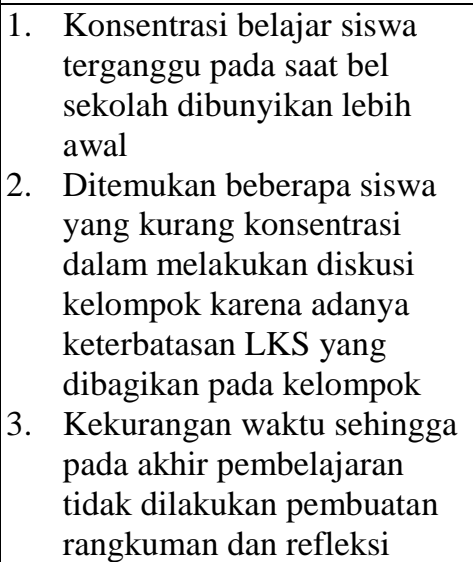 & $\begin{array}{l}\text { 1. Ditemukan } 2 \text { orang siswa } \\
\text { yang menggunakan } \\
\text { peralatan prakrikum untuk } \\
\text { keperluan lain yang tidak } \\
\text { terkait dengan } \\
\text { pembelajaran } \\
\text { 2. Beberapa siswa tidak fokus } \\
\text { pada kegiatan demonstrasi } \\
\text { yang dilakukan oleh guru } \\
\text { karena mencoba peralatan } \\
\text { praktikum yang dibagikan } \\
\text { guru }\end{array}$ & $\begin{array}{l}\text { 1. Mengkomunikasikan dengan } \\
\text { pihak-pihak terkait supaya } \\
\text { tidak membunyikan bel } \\
\text { sekolah sebelum kegiatan } \\
\text { belajar diselesaikan } \\
\text { 2. Jumlah LKS harus } \\
\text { disesuiakan dengan jumlah } \\
\text { kelompok } \\
\text { 3. Manajemen waktu } \\
\text { pembelajaran dan pembagian } \\
\text { peralatan praktikum } \\
\text { dibagikan setelah kegiatan } \\
\text { demonstrasi }\end{array}$ \\
\hline
\end{tabular}

Rangkuman hasil refleksi kegiatan Lesson Study yang ada pada Tabel 3 menunjukkan beberapa kejadian penting dalam pembelajaran yang dapat dijadikan sebagai bahan masukan untuk melakukan perbaikan dalam merencanakan dan melaksanakan pembelajaran. Apabila ditelusuri lebih lanjut hasil refleksi pada Tabel 3 tersebut kejadian penting yang terjadi dalam pembelajaran dapat dikelompokkan menjadi 5 bagian. Kelima bagian tersebut ialah (1) aktivitas siswa yang mengganggu siswa lain seperti ribut, ngobrol yang tidak terkait dengan materi, dan siswa pasif; (2) kendala teknis pemutaran video yang 
terputus karena daya listrik yang tidak mencukupi; (3) persiapan dan kelengkapan bahan praktikum yang tidak sesuai dengan jumlah siswa; (4) waktu pelaksanaan kegiatan praktikum dan pengamatan yang kurang; dan (5) gannguan teknis yang mengganggu konsentrasi belajar siswa karena bel sekolah yang memulangkan siswa tidak sesuai dengan jadwal yang seharusnya.

Kejadian pada point 1 (aktivitas siswa yang menggangu) terjadi pada pembelajaran yang dikelola oleh semua guru model M1 - NI, M2 - HS, M3 AA, M4 - EK, M5 - KM, dan M6 - MH. Kejadian ini sejalan dengan hasil angket yang dibagikan kepada siswa (Tabel 2) yang menyatakan bahwa dalam setiap pembelajaran ditemukan kejadian yang tidak penting dilakukan oleh siswa yaitu bermain/ngobrol pada saat belajar/diskusi kelompok. Kejadian pada point 2 (teknis pemutaran video) terjadi pada guru model M4 - EK dan M5 - KM. Sementara itu kejadian pada point 3 (kegiatan praktikum) ditemukan pada pembelajaran yang dilaksanakan oleh guru model M1 - NI, M2 - HS, dan M4 - EK. Kejadian lain yang tidak dikehendaki dalam pembelajaran terjadi pada guru model M5 KM dan M6 - MH yaitu kekurangan waktu dalam melaksanakan kegiatan pengamatan dan praktikum. Gangguan teknis lain yang terjadi selama melaksanakan pembelajaran berbasis Lesson Study di SMP 4 Lingsar ialah bunyi bel sekolah yang mengisyaratkan siswa pulang lebih awal karena cuaca mendung dan ada kegiatan sekolah yang tidak dikomunikasikan terlebih dahulu dengan guru model yang sedang melaksanakan kegiatan pembelajaran.

Pada tahap refleksi, analisis pelaksanaan pembelajaran dilakukan oleh guru model, pengamat, dan dosen pembimbing. Pengamat menyampaikan komentar kelebihan dan kekurangan, saran, dan pertanyaan terkait pelaksanaan pembelajaran serta perangkat pembelajaran yang digunakan. Pada refleksi sesi pertama, analisis dan masukan dari guru model lebih pada keterampilan mengajar namun tidak pada strategi pembelajaran yang diterapkan. Berbeda dengan masukan dari pengamat dan dosen pembimbing tidak hanya terkait keterampilan mengajar yang dikembangkan namun juga proses pembelajaran dengan strategi yang mendorong siswa menemukan konsep [11]. Pada dasarnya, selama sesi refleksi guru model dapat mengeksplor dan mempelajari banyak aspek pengajaran dan pembelajaran [12]. Kondisi seperti ini dapat dijadikan wahana pembelajaran antar guru yang dapat memberikan kontribusi untuk memperbaiki kegiatan pembelajaran. Hal ini sejalan dengan hasil penelitian yang dilakukan oleh Sims dan Walhs [13]. Namun demikian, refleksi pembelajaran berbasiss Lesson Study ini sangat rentan terhadap adanya unsur subjektif dalam meberikan informasi terkait dengan hasil pengematan. Terlebih lagi kalau unsur subjektif ini dikaitkan dengan budaya ketimuran yang tidak mudah dalam menerima kritik dan masukan dari orang lain. Lebih lanjut Mahmudi [14] menyatakan bahwa meskipun semangat yang terkandung dalam Lesson Study adalah saling belajar, namun mengingat budaya kita yang belum terbiasa dan tidak mudah untuk menerima kritik secara langsung, maka disarankan fokus evaluasi adalah pada bagaimana respon siswa terhadap pembelajaran yang dilaksanakan. Hal ini disebabkan oleh adanya informasi lain bahwa tanggapan guru model yang dilakukan di tempat lain pada kegiatan Lesson Study dilakukan guru model merasa "nervous" ketika tampil di depan kelas (40\%), tetapi setelah pembelajaran berlangsung mereka bisa menguasai diri dan dapat mengajar dengan baik [15].

\section{KESIMPULAN}

Berdasarkan hasil praktek mengajar pada perkuliahan pemantapan kemampuan mengajar yang dilaksanakan di SMP 4 Lingsar dapat disimpulkan bahwa (1) pembelajaran yang dilakukan oleh guru model secara umum menarik bagi siswa untuk melaksanakan kegiatan pembelajaran meskipun masih ditemukan siswa kurang serius, kurang disiplin, mengobrol dan melakukan aktivitas yang menggangu siswa lain pada saat diskusi kelompok, (2) persiapan guru model sebelum melaksanakan kegiatan pembelajaran perlu dimatangkan untuk mengantisipasi kekurangan peralatan dan bahan pada saat melakukan kegiatan pengamatan maupun praktikum, dan (3) optimalisai kemampuan guru model dalam mengelola kelas terutama dalam memfasilitasi diskusi kelompok, dan (4) pelaksanaan pembelajaran berbasis Lesson Study yang telah dilaksanakan mengalami kendala teknis yang tidak perlu terjadi seperti kurangnya daya listrik, bel sekolah yang memulangkan siswa lebih awal, dan rombongan belajar yang melebihi dari ketentuan normal yang dipersyaratkan.

\section{DAFTAR PUSTAKA}

[1.] Parno, 2009. Deskripsi Pelaksanaan Penggabungan LS dan PTK oleh Mahasiswa Program Sertifikasi Guru dalam Jabatan melalui Jalur Pendidikan. Prosiding Seminar Nasional Penelitian, Pendidikan dan PenerapanMIPA, Fakultas MIPA, Universitas Negeri Yogyakarta.

[2.] Subadi, T. 2009. Peningkatan Kualitas Pembelajaran Micro Teaching dan PPL (Program Pengalaman Lapangan) Melalui Lesson Study Bagi Calon Guru. Jurnal Varia Pendidikan, Vol. 21 (2): 189-198.

[3.] Rusman. 2010. Model-model Pembelajaran. Bandung: Mulian Mandiri Press.

[4.] Puchner, L.D. dan A.R. Taylor. 2006. Lesson Study, Collaboration and Teacher Efficacy: Stories from Two School-Based 
Math Lesson Study Groups. Teaching and Teacher Education 22: 922-934.

[5.] Hendayana dan Sumar. 2007. Lesson Study, Suatu Strategi untuk Meningkatkan Keprofesionalan Pendidik (Pengalaman IMSTEP-JICA). Bandung: UPI Press.

[6.] Doig, B. dan S. Groves. 2011. Japanese Lesson Study: Teacher Professional Development through Communities of Inquiry. Mathematics Teacher Education and Development, Vol. 13(1): 77-93.

[7.] Putri, N. 2012. Efektifitas Penggunaan Media Video untuk Meningkatkan Pengenalan Alat Musik Daerah pada Pembelajaran IPS bagi Anak Tunagrahita Ringan Di Sdlb 20 Kota Solok. Jurnal Ilmiah Pendidikan Khusus, Vol. 1 (2): 318328.

[8.] Rebowo, W. A. 2014. Pengembangan Media Video Pembelajaran Berbasis Masalah Materi Pecahan Pada Siswa Kelas IV Sekolah Dasar. Jurnal Pelangi Pendidikan, Vol. 21 (2): 94-106.

[9.] Wasilah, E.B. 2012. Peningkatan Kemampuan Menyimpulkan Hasil Praktikum IPA Melalui Penggunaan Media Kartu. Jurnal Pendidikan IPA Indonesia, Vol.1 (1) : 82-90.
[10.] Lamasai, M. M. M. dan R. I. Puadi. 2014. Pemanfaatan Lingkungan Alam Sekitar Sebagai Sumber Belajar Dalam Meningkatkan Hasil Belajar IPA Siswa Kelas III SDN 10 Gadung. Jurnal Kreatif Tadulako Online Vol. 5 (3): 132-144.

[11.] Aryulina, D. 2010. Penerapan Lesson Study pada Microteaching bagi Calon Guru Biologi. Jurnal Forum Kependidikan, Vol. 30 (1): 14-19.

[12.] Suratno, T. dan S. Iskandar. 2010. Teacher reflection in Indonesia: Lessons learnt from a lesson study program. US-China Education Review. Vol 7 (12): 39-48.

[13.] Sims, L. dan D. Walsh. 2009. Lesson Study with preservice teachers: Lessons from lessons. Teaching and Teacher Education 25: 724-733.

[14.] Mahmudi, A. 2009. Mengembangkan Kompetensi Guru melalui Lesson Study. Jurnal Forum Kependidikan, Vol. 28 (2): 84-89.

[15.] Sriyanti, S. 2007. Peningkatan Profesionalisme Guru dan Kualitas Pembelajaran Biologi di Sekolah Melalui Lesson Study. Jurnal Pengajaran MIPA, Vol. 9 (1): 10-19. 